\title{
Coral recruitment in blasted and unblasted sites in Indonesia: assessing rehabilitation potential
}

\author{
Helen E. Fox ${ }^{*}$ \\ Department of Integrative Biology, University of California, Berkeley 94720-3140, California, USA \\ Present address: Hawaii Institute of Marine Biology, PO Box 1346, Kaneohe, Hawaii 96744, USA
}

\begin{abstract}
Widespread blast fishing destroys living scleractinian corals and creates vast fields of shattered coral rubble that can only recover to coral dominance through a successional process that includes coral recruitment. Given the extent of damaged areas on many SE Asian reefs, successful recruitment and survival of juvenile corals will be important components of either natural recovery or human-assisted rehabilitation. Early scleractinian coral recruitment to tiles was assessed in blasted and unblasted sites in Komodo National Park, Indonesia, from 1998 to 2000. A total of 6530 corals recruited to 527 tiles (each $400 \mathrm{~cm}^{2}$ ), primarily of the families Acroporidae $(27.1 \%)$, Pocilloporidae $(44.7 \%)$ and Poritidae (12\%). Acroporids settled primarily during NW monsoon months (October-April), while pocilloporids and poritids settled year-round. Standardized recruitment rates averaged from 285 to 772 spat $\mathrm{m}^{-2} \mathrm{yr}^{-1}$ across all sites, with a site maximum of 2663 spat m ${ }^{-2} \mathrm{yr}^{-1}$. While significant spatial and temporal variation was detected across sites and seasons, no significant difference in abundance of coral spat was found between blasted and unblasted sites. Results from this study suggest that these blasted sites are not recruitment-limited, and that failure of corals to recover in rubble fields is due to post-settlement mortality.
\end{abstract}

KEY WORDS: Coral settlement $\cdot$ Recruitment $\cdot$ Recovery $\cdot$ Dynamite fishing $\cdot$ Blast fishing $\cdot$ Indonesia Resale or republication not permitted without written consent of the publisher

\section{INTRODUCTION}

Coral recruitment is a crucial precursor to recovery of reefs damaged by disturbance events (Connell 1997, Syms \& Jones 2000). Settlement and recruitment patterns can vary according to the cover of live coral in the source populations, abundance and diversity of the pool of coral larvae, hydrodynamic variation, grazing pressure, light levels, and connectivity between reefs (Sammarco 1980, Wallace 1985, Done 1992, Maida et al. 1994, Roberts 1997, Hughes et al. 1999). Recruitment has been studied after several types of disturbances including bleaching (Gleason 1996, Edwards et al. 2001, Loch et al. 2002), cyclones (Connell et al. 1997), crown-of-thorns starfish (Acanthaster planci) infestations (Wallace et al. 1986, Harriot \& Fisk 1989), ship groundings (Smith 1988), and dynamite fishing (Nzali et al. 1998). Nzali et al. (1998) found significantly lower recruitment at a blasted, low coral cover site than at an unblasted, high coral cover site in Tan- zania. However, other studies have shown that recruitment can remain high in the absence of local adult coral populations (Harriott \& Fisk 1988). Sites that are recruitment-limited may not recover naturally, so may need additional intervention such as coral transplantation (Edwards \& Clark 1998).

Settlement tiles, onto which coral larvae attach and can thus be examined microscopically, are useful for determining general trends in larval availability, and have provided insight into local and regional patterns of recruitment (the point at which corals become visible to census; Harrison \& Wallace 1990). Growth and survival of settled spat can be influenced by a variety of post-settlement mortality processes (Bak \& Engel 1979, Babcock 1991, Connell et al. 1997, Smith 1997). Studies of early recruitment to tiles have been conducted primarily on the Great Barrier Reef (Wallace 1985, Harriott \& Fisk 1987, 1988, 1989, Fisk \& Harriott 1990, Baird \& Hughes 1997, Dunstan \& Johnson 1998, Hughes et al. 1999) and other parts of 
Australia (Harriott \& Banks 1995, Harriott 1999), as well as in the Caribbean (Bak \& Engel 1979, Rogers et al. 1984, Gunkel 1997), Bermuda (Smith 1992), Hawaii (Fitzhardinge 1988, E. Brown \& S. Kolinski pers. comm.), and Florida (Smith 1997), with fewer in east Africa (Nzali et al. 1998) and the southcentral Pacific (Gleason 1996). Tomascik et al. (1996) reported rapid coral colonization of a lava flow in the Banda Islands (also in eastern Indonesia), although they did not use settlement tiles to examine early recruitment. Few published accounts exist that provide larval recruitment data for the region of highest coral biodiversity, the Indowest Pacific (but see Nacua \& Alino 1994, Raymundo \& Maypa 1997, Reyes \& Yap 2001).

The study presented here assessed settlement and early recruitment of coral spat in blasted and unblasted sites as part of a larger project assessing natural coral recovery and rehabilitation techniques in large rubble fields created by blast fishing. Blast fishing in Indonesia originated with excess munitions from World War II, and today consists of homemade kerosene and fertilizer bombs packed in glass or plastic bottles (Pet-Soede \& Erdmann 1998). The detonated bombs' shockwaves not only kill fish and other organisms within the 1 to $5 \mathrm{~m}$ blast radius, but also pulverize the coral skeletons themselves (Alcala \& Gomez 1987, McManus 1997).

The objectives of this study were (1) to provide the first estimates of larval coral recruitment to settlement tiles in eastern Indonesia, including seasonal and taxonomic variation; (2) to determine if there were differences in settlement of coral spat between blasted, rubble-dominated sites and unblasted, coral-dominated sites, and (3) to assess settlement levels in the blasted sites to determine if sufficient recruitment exists to support natural recolonization of rehabilitation treatments.

\section{MATERIALS AND METHODS}

Study site. Komodo National Park (KNP), in eastern Indonesia between the major islands of Sumbawa and Flores $\left(08^{\circ} 29-38^{\prime} \mathrm{S}, 1^{\circ} 9^{\circ} 33-43^{\prime} \mathrm{E}\right.$, Fig. 1), is biologi- cally diverse with many different reef types and many rare species (Best \& Boekschoten 1988). The Snellius-II expedition in 1984 recorded 225 species from NE Komodo (Best et al. 1989), and a Rapid Ecological Assessment (REA) conducted in 1995 estimated 260 species of reef-building corals and $\sim 1000$ fish species in KNP (Holthus 1995); G. Allen has collected 736 fish species from Komodo (Tomascik et al. 1997). The REA also estimated that more than $50 \%$ of the coral reefs inside the park had suffered damage from destructive fishing practices, primarily blast fishing, which has occurred at varying levels in KNP since the early 1950s (Holthus 1995).

Plots $\sim 30 \times 10 \mathrm{~m}$ were established 6 to $10 \mathrm{~m}$ deep within 9 rubble fields created by chronic blast fishing. Sites selected from previously identified rubble fields 500 to $3000 \mathrm{~m}^{2}$ in size (Fox et al. 2001) spanned the NE quadrant of the park, and represented a variety of cur- 
rent strengths (Fig. 1). Relative current strength was measured using dissolving plaster-of-Paris blocks ( $45 \mathrm{~g}$ initial weight, 3 hemispherical blocks per site at each of 3 separate $24 \mathrm{~h}$ time periods) (Jokiel \& Morrissey 1993). Numbers of visible juveniles in the rubble fields ( $1 \mathrm{~cm}$ and larger diameter) were assessed every 6 mo over 3 yr (1998 to 2000) by surveying location, number, size, life form and taxon (if known) of hard coral recruits within 10 randomly selected $1 \times 1 \mathrm{~m}$ quadrats per site (Fox et al. 2003). Plots $\sim 30 \times 10 \mathrm{~m}$ were also established near 6 of the rubble fields (within $\sim 0.5$ to $6.5 \mathrm{~km}$ ) on reefs that were relatively undamaged by blasting and also had varied current strengths (Fig. 1). These 'unblasted' sites were not necessarily unimpacted, as it is impossible to know the past history of most sites in KNP, and there are few, if any, locations that have been free from all anthropogenic impact. However, these sites did have much higher live coral coverage and much lower abundance of rubble: unblasted sites had an average of $59 \%$ live coral and $7 \%$ rubble compared to blasted sites, which had an average of $5 \%$ live coral and $82 \%$ rubble (Fox 2002; assessed using line-intercept transects, English et al. 1997).

Settlement tiles. Settlement tiles were deployed in the rubble fields and in adjacent paired high coral cover sites. The settlement tiles were $10 \times 20 \times 0.7 \mathrm{~cm}$ in size with a terra cotta front ('glazed') and unfinished back surface ('unglazed'). Pairs of tiles were sandwiched around a narrow wooden plank $(\sim 30 \times 2.5 \times$ $1.5 \mathrm{~cm}$ ) to create a gap of approximately 1 to $2 \mathrm{~cm}$ between the tiles (Fig. 2). The gap provided a protected environment favorable to coral settlement (Harriott \& Fisk 1987, 1988). One glazed and 1 unglazed surface from each tile faced into the gap for a total of 4 face surfaces: glazed gap, unglazed gap, glazed outer, unglazed outer. Five pairs (10 tiles per site) were installed in 9 blasted and 6 unblasted sites, 1 at each corner of the $30 \times 10 \mathrm{~m}$ plot and the fifth in the center.

While Mundy (2000) suggested that it is preferable to deploy settlement plates attached directly to the reef surface, this was not practical in this case, because the rubble field did not form a solid substrate (nor did the standing, branching coral at many locations in the unblasted sites). Furthermore, the rubble shifts significantly over the course of days and months (Fox et al. 2003), which would bury plates deployed at substratelevel. Therefore, each tile pair was attached to rebar posts driven into the substrate so that the tiles were approximately $25 \mathrm{~cm}( \pm 5 \mathrm{~cm})$ above the substrate and were vertically oriented (Fig. 2). This orientation was selected to reduce sedimentation (Fisk \& Harriott 1990) and enhance settlement (Babcock \& Mundy 1996). Tiles were collected and replaced approximately every 6 mo, starting in April 1998 for 3 rubble sites (BZ, NK,

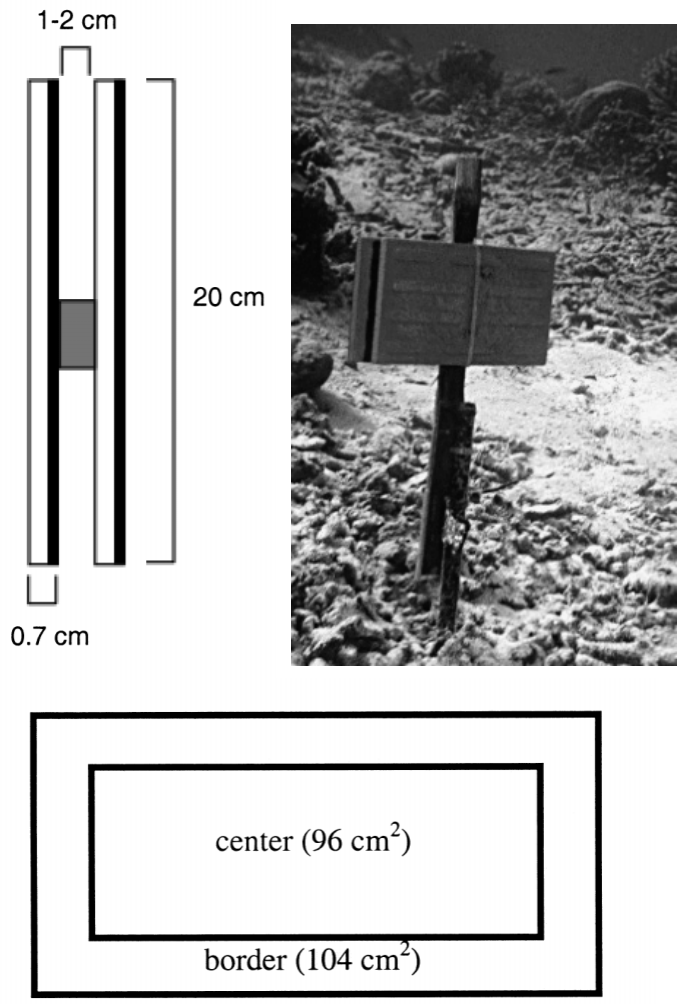

Fig. 2. Left: top view of settlement tile pair with planks (gray rectangle) in between the gap. Tiles are $20 \mathrm{~cm}$ wide by $10 \mathrm{~cm}$ high. The dark shading represents the glazed side of the tile, so that 1 glazed and 1 unglazed surface face into the gap (1 to $2 \mathrm{~cm}$ wide). Right: Photograph of settlement tile pair deployed in a rubble field. Bottom: schematic showing the center and border areas of each tile face

NP) and October 1998 for the remaining 6 rubble sites. Tiles for the 6 unblasted sites were first deployed in April 1999. The final collection for all tiles was in October 2000. 'SE monsoon' seasons were April to October, and 'NW monsoon' seasons were October to April.

Collected tiles were bleached in a dilute chlorine solution, sun-dried, and each face of the tile was examined with a dissection microscope (100 to $500 \times$ ). The tile edges were not examined. Cartesian locations on the tile face (to the nearest $\mathrm{cm}$ ), size (measured with a micrometer in the microscope ocular), and, where possible, family of the coral spat, were identified. Using the Cartesian locations, the tile faces were divided into an outer border $2 \mathrm{~cm}$ in width $\left(104 \mathrm{~cm}^{2}\right)$ and the remaining central area $\left(96 \mathrm{~cm}^{2}\right)$ to compare settlement on borders vs the central area (Fig. 2). Standardized recruitment rates were calculated (number of spat in blasted or unblasted sites $\mathrm{m}^{-2} \mathrm{yr}^{-1}$, Smith 1992).

Statistical analysis. Data were transformed as $\ln$ $(x+1)$ to homogenize variances. Homogeneity of variances was tested with Cochran's $C$ (Winer et al. 1991). For analysis of differences in settlement between 
Table 1. Mixed-model ANOVA of the effect of season, blast history, and paired sites on numbers of scleractinian coral recruits to tiles (see Fig. 1 for site pairings). From top: all corals, acroporids, pocilloporids, and poritids. Counts of spat numbers $(+1)$ were ln-transformed. p-values are shown, unless not signifficant (ns)

\begin{tabular}{|c|c|c|c|c|}
\hline Source & df & MS & Adjusted $F$ & $\mathrm{p}$-value \\
\hline \multicolumn{5}{|l|}{ All spat } \\
\hline Season (fixed) & 2 & 9.46 & 17.21 & $\mathrm{p}<0.0025$ \\
\hline Blasted/not (fixed) & 1 & 0.15 & 0.00 & ns \\
\hline Paired sites (random) & 4 & 7.53 & 17.32 & $\mathrm{p}<0.00005$ \\
\hline Season $\times$ Blast & 2 & 1.86 & 1.13 & ns \\
\hline Season $\times$ Paired sites & 8 & 0.55 & 1.26 & ns \\
\hline Blast $\times$ Paired sites & 4 & 32.14 & 73.94 & $\mathrm{p}<0.00005$ \\
\hline Season $\times$ Blast $\times$ Paired sites & 8 & 1.64 & 3.78 & $\mathrm{p}<0.00005$ \\
\hline Error & 245 & 0.43 & & \\
\hline Total & 274 & & & \\
\hline \multicolumn{5}{|l|}{ Acroporids } \\
\hline Season (fixed) & 2 & 58.63 & 120.93 & $\mathrm{p}<0.0005$ \\
\hline Blasted/not (fixed) & 1 & 0.25 & 0.13 & ns \\
\hline Paired sites (random) & 4 & 1.41 & 3.95 & $\mathrm{p}<0.005$ \\
\hline Season $\times$ Blast & 2 & 2.19 & 5.96 & $\mathrm{p}<0.05$ \\
\hline Season $\times$ Paired sites & 8 & 0.48 & 1.36 & $\mathrm{~ns}$ \\
\hline Blast $\times$ Paired sites & 4 & 1.97 & 5.53 & $\mathrm{p}<0.0005$ \\
\hline Season $\times$ Blast $\times$ Paired sites & 8 & 0.37 & 1.03 & ns \\
\hline Error & 245 & 0.36 & & \\
\hline Total & 274 & & & \\
\hline \multicolumn{5}{|l|}{ Pocilloporids } \\
\hline Season (fixed) & 2 & 1.77 & 2.76 & ns \\
\hline Blasted/not (fixed) & 1 & 0.19 & 0.00 & ns \\
\hline Paired sites (random) & 4 & 13.85 & 39.11 & $\mathrm{p}<0.00005$ \\
\hline Season $\times$ Blast & 2 & 2.70 & 1.47 & ns \\
\hline Season $\times$ Paired sites & 8 & 0.64 & 1.81 & ns \\
\hline Blast $\times$ Paired sites & 4 & 39.78 & 112.29 & $\mathrm{p}<0.00005$ \\
\hline Season $\times$ Blast $\times$ Paired sites & 8 & 1.84 & 5.19 & $\mathrm{p}<0.00005$ \\
\hline Error & 245 & 0.35 & & \\
\hline Total & 274 & & & \\
\hline \multicolumn{5}{|l|}{ Poritids } \\
\hline Season (fixed) & 2 & 1.69 & 2.22 & ns \\
\hline Blasted/not (fixed) & 1 & 8.23 & 3.66 & ns \\
\hline Paired sites (random) & 4 & 6.34 & 20.35 & $\mathrm{p}<0.00005$ \\
\hline Season $\times$ Blast & 2 & 0.04 & 0.07 & ns \\
\hline Season $\times$ Paired sites & 8 & 0.76 & 2.44 & $\mathrm{p}<0.05$ \\
\hline Blast $\times$ Paired sites & 4 & 2.25 & 7.23 & $\mathrm{p}<0.00005$ \\
\hline Season $\times$ Blast $\times$ Paired sites & 8 & 0.63 & 2.02 & $\mathrm{p}<0.05$ \\
\hline Error & 245 & 0.31 & & \\
\hline Total & 274 & & & \\
\hline
\end{tabular}

blasted and unblasted sites and between seasons, a mixed model ANOVA was constructed with site locations as a random block factor and blasted/not blasted and season as fixed factors. Normality of residuals was assessed using the Shapiro-Wilk test. Lost or broken tiles were not used in the analysis. The paired sites BP/LP (Back of Papagarang and Little Papagarang) were eliminated from the mixed model ANOVA since there were only 2 tiles (of 10 deployed) collected at the unblasted site of Little Papagarang in October 1999, although counts were included in the settlement totals (Table 2). Wilcoxon signed rank tests were used to com- pare settlement to glazed vs unglazed and gap vs outer surfaces (since assumptions of normality were not met when data were split by family). Kruskal-Wallis 1-way ANOVAs were used to compare family differences in settlement preferences and size of spat.

\section{RESULTS}

\section{Recruitment patterns}

Recruitment to tiles was highly variable across sites and seasons, and was not correlated with current strength (Table 1, Fig. 3, p > 0.05, Pearson correlations, based on percent dissolution of plaster blocks). Most sites had an average of 3 to 20 spat per tile, for a total of 6530 scleractinian corals recruited to 527 tiles of the 580 tiles deployed (400 at blasted sites, 180 at unblasted sites). Most of the 53 lost, broken, or missing tiles had been deployed at the unblasted sites; perhaps more were lost due to the greater fishing activity at those sites (author's pers. obs.). The dominant families settling were Pocilloporidae $(44.7 \%)$, Acroporidae $(27.1 \%)$, and Poritidae $(12 \%)$. The remaining spat were unidentified $(16.3 \%)$. Acroporids settled primarily in the NW monsoon months, while pocilloporids and poritids did not display similar seasonal differences (Table 1), though the NW monsoon of 2000 was a peak recruitment season across families (Fig. 4). Overall, a total of $62.2 \%$ of all spat settled in the NW monsoon months, and $37.8 \%$ settled in SE monsoon months.

More recruitment occurred inside the gap between tiles than on the outer tile faces (Fig. 5). This difference between the 2 surfaces varied by season, and was driven by preferred settlement of pocilloporids onto surfaces in the gap (Fig. 5; Kruskal-Wallis ANOVA $F=15.6, \mathrm{p}<0.001)$. Acroporids settled more commonly on the outer tile faces. Approximately equal numbers settled towards the center and the border (96 vs $104 \mathrm{~cm}^{2}$ in surface area) of the outer faces, while 2 to 3 times as many spat settled towards the border rather than in the center of the faces in the 


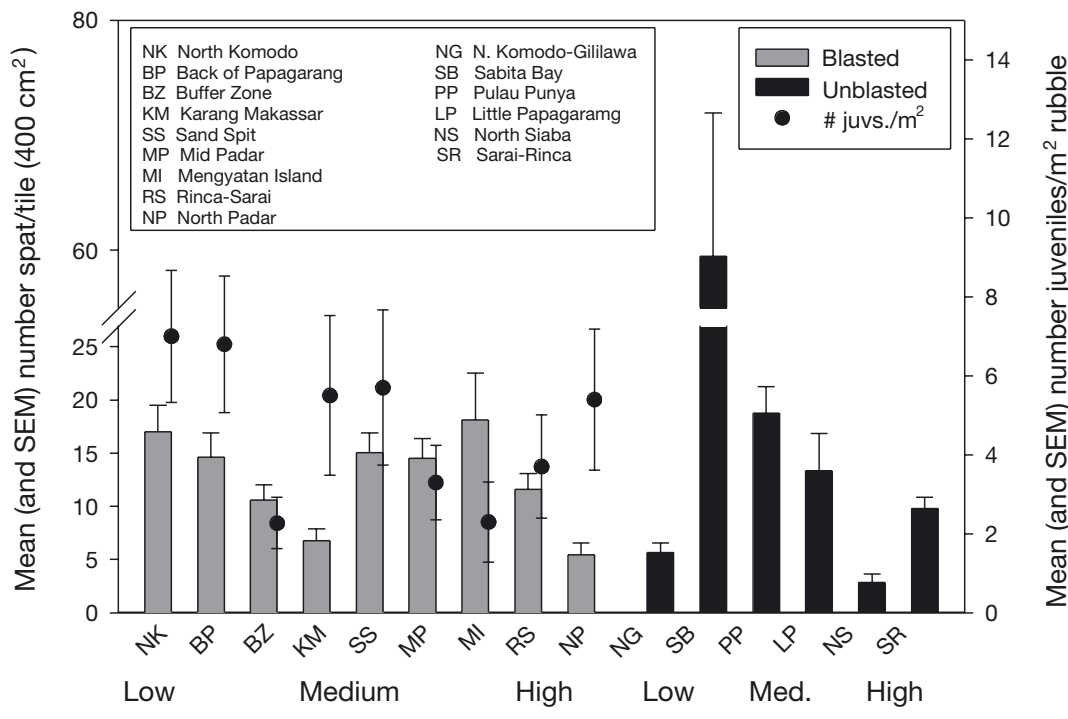

Sites and Current Strength

Fig. 3. Left $y$-axis (bars): mean number of recruits per tile (and SEM) at 9 blasted sites and 6 unblasted sites, pooled over 3 seasons (SE monsoon 1999, NW monsoon 2000, and SE monsoon 2000). Note break for Site SB. Sites are ordered from low to high relative current strength within each category. While there are differences in recruitment between sites, there are no significant differences between blasted and unblasted sites. Right $y$-axis (points): mean number of juvenile corals per $\mathrm{m}^{2}$ (and SEM) based on surveys in 10 random $1 \times 1 \mathrm{~m}$ quadrats per site in October 2000

gap (Table 2). No preference was evident for settlement on the glazed terra cotta surface of the tile vs the unglazed surface (Wilcoxon Signed Rank test, $p>0.05$ ). Pocilloporid recruits were largest, followed by acroporids and poritids/unidentified (Kruskal-Wallis ANOVA, $F=443.2$, $\mathrm{p}<0.005)$, with a wide range for all families (Table 3). Corals settling to the gap surfaces were larger than those facing outward (Wilcoxon signed rank test, $\mathrm{p}<0.0001$ ).

\section{Blasted vs. unblasted sites}

Higher local coral cover did not necessarily result in increased local settlement. No significant difference was found between settlement to tiles at paired blasted vs unblasted sites for either total coral counts (Tukey's HSD post-hoc tests for each season, $p>0.05$, Fig. 6), or when split by coral family (Table 1). Standardized recruitment rates for Komodo National Park averaged from 285 to 772 spat $\mathrm{m}^{-2} \mathrm{yr}^{-1}$ at

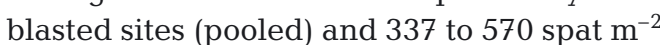
$\mathrm{yr}^{-1}$ at unblasted sites (pooled, Site SB omitted). An examination of the patterns of settlement at the 5 deployment locations within each $300 \mathrm{~m}^{2}$ site did not reveal any clear differences, suggesting consistent levels of settlement within 10 to $30 \mathrm{~m}$.

\section{Rehabilitation potential}

Results indicate that blasted sites are unlikely to be recruitment-limited, as ample settlement occurred, ranging from 270 to 900 recruits $\mathrm{m}^{-2} \mathrm{yr}^{-1}$ at the 9 sites. The lowest and highest settlement levels were in unblasted sites: the lowest settlement was observed at North Siaba (overall mean of 2.87 ( \pm 0.77 SEM) spat per tile; standardized recruitment rate of $135 \mathrm{~m}^{-2} \mathrm{yr}^{-1}$ ), and the highest settlement occurred at Sabita Bay (59.44 ( \pm 12.49 SEM) spat per tile; standardized recruitment rate of $\left.2663 \mathrm{~m}^{-2} \mathrm{yr}^{-1}\right)$. Sabita Bay was the only site to have consistently high recruitment; at other sites, recruitment varied across seasons as much as across locations.

Settlement to tiles at blasted sites (a rough proxy for available coral source larvae) was not correlated with the numbers of visible coral juveniles found from surveying the rubble substrate at each of those sites, suggesting differential post-settlement survival of spat (Fig. 3, $p>0.05$, Pearson correlations).

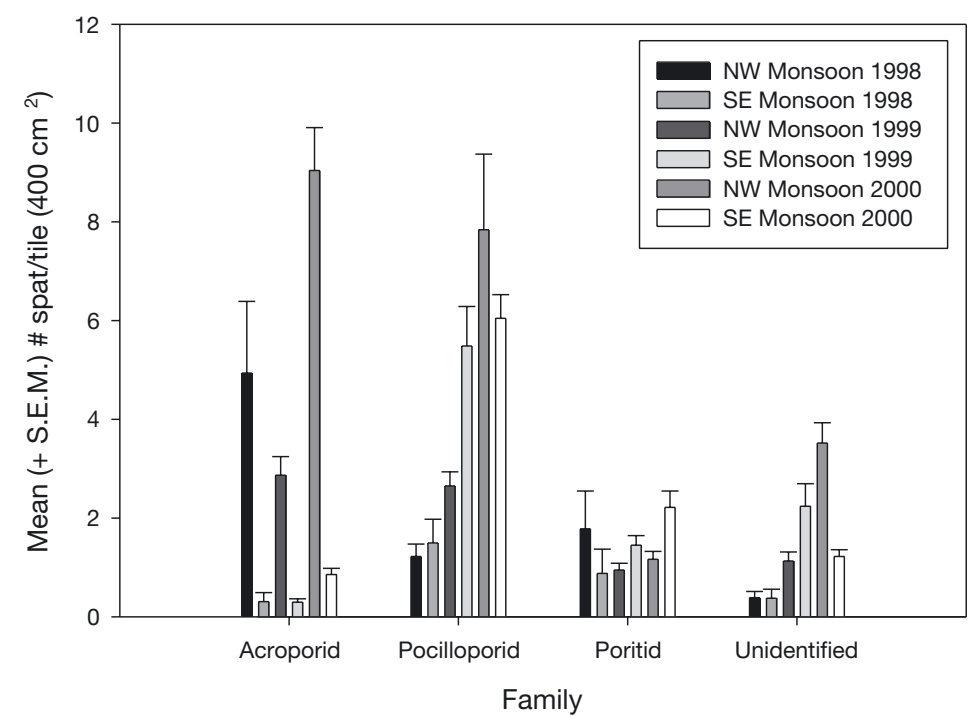

Fig. 4. Mean number (and SEM) of hard coral spat per tile $\left(400 \mathrm{~cm}^{2}\right.$ each) of the main family groups at each season. Acroporids show significantly increased settlement in the NW monsoon; no other family has a seasonal preference 


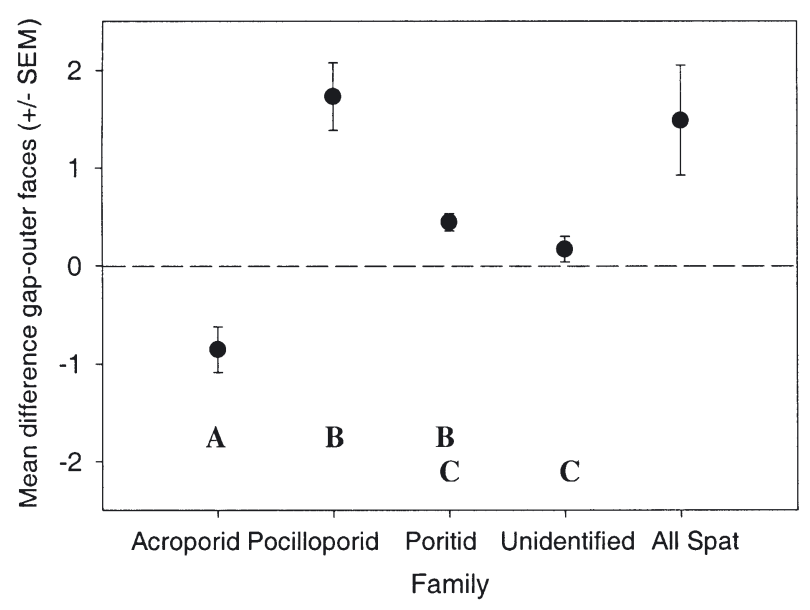

Fig. 5. Mean difference (and SEM) in number of coral spat of the main family groups, unidentified spat, and all spat, between the gap and outer faces $\left(200 \mathrm{~cm}^{2}\right.$ each). Shared letters are not statistically different. Dots above the zero line settled preferentially in the gap; dots below the line settled preferentially on outer tile surfaces

\section{DISCUSSION}

\section{Recruitment patterns}

Although considerable variation existed across sites, significant differences in coral settlement densities between blasted and unblasted sites were not found, suggesting that blasted sites are not recruitmentlimited. The average levels of scleractinian coral recruitment to tiles in Komodo are comparable to rates found for the Great Barrier Reef and higher than most rates reported for Bermuda, the Caribbean, and other parts of the Pacific (standardized recruitment for a number of studies with tiles deployed from 3 to 12 mo, as reported in Smith 1992).

Results indicate that source populations of corals existed within the range for larval dispersal by currents. Currents in Komodo National Park are very strong at some sites (Holthus 1995), which would lead to considerable mixing and transport of larvae with the ebb and flood tides. The minimum time it takes for planulae to become competent to settle is 1 to $4 \mathrm{~d}$ for many corals (Babcock \& Heyward 1986). The maximum time larvae from brooders are predicted to remain competent is at least $100 \mathrm{~d}$ (Richmond 1988, Harii et al. 2002), and larvae of various species of broadcast spawners have been found to remain competent from 26 to 91 d (Harrison et al. 1984, Wilson \& Harrison 1998). Such competency periods would enable considerable long-distance dispersal throughout the Komodo region, although small-scale currents also play a key role in settlement (Koehl et al. 1998). The relative level of brooding vs broadcast-spawning corals in KNP is unknown, although acroporids are primarily spawners, pocilloporids are primarily brooders, and poritids are mixed (Harrison \& Wallace 1990).

Family differences drive the overall seasonal differences in settlement. Harriott \& Fisk (1988) found that pocilloporids recruited year-round in the northern GBR $_{i}$ Gleason (1996) found this to be true for both pocilloporids and poritids in Moorea, French Polynesia. As in other studies (Harriott \& Fisk 1988, Fisk \& Harriott 1990), acroporids in Komodo had a seasonal peak in October through April, suggesting that their spawning season occurs during this period. Synchronized coral spawning in eastern Indonesia has not yet been reported, although mass spawning was reported in the central Java Sea during October and November 1995 (Tomascik et al. 1997).

The taxonomic difference in settlement to the tile gap may be due to the different light intensity between

Table 3. Mean sizes (SEM) and range of colony diameters for the main identified families. Rows which share letters are not statistically different (Kruskal-Wallis ANOVA). Tiles were in place for approximately 6 mo

\begin{tabular}{|c|c|c|c|c|}
\hline \multirow[t]{2}{*}{ Family } & \multicolumn{2}{|c|}{ Mean diameter } & \multirow{2}{*}{$\begin{array}{c}\text { Range } \\
\mathrm{mm}\end{array}$} & \multirow{2}{*}{$\begin{array}{c}\text { Statistical } \\
\text { sig. }\end{array}$} \\
\hline & $\mathrm{mm}$ & SEM & & \\
\hline Acroporidae & 1.67 & $(0.04)$ & $0.5-22$ & A \\
\hline Pocilloporidae & 2.15 & $(0.04)$ & $0.6-24$ & B \\
\hline Poritidae & 1.40 & $(0.05)$ & $0.4-12$ & $\mathrm{C}$ \\
\hline Unidentified & 1.16 & $(0.02)$ & $0.3-9$ & $\mathrm{C}$ \\
\hline
\end{tabular}

Table 2. Distribution of numbers of coral spat per $\mathrm{m}^{2}$ (total numbers in parentheses) settling on the border vs. center areas of the tile faces (see Fig. 2) for both gap and outer faces in blasted and unblasted sites

\begin{tabular}{|lllll|}
\hline Sites & Habitat & No. $\mathrm{m}^{-2}$ spat center (tot. no.) & No. $\mathrm{m}^{-2}$ spat border (tot. no.) & Totals \\
\hline Blasted sites; 381 tiles & Gap & $138.3(506)$ & $398.5(1579)$ & $273.6(2085)$ \\
& Outer & $299.1(1094)$ & $247.3(980)$ & $272.2(2074)$ \\
Unblasted sites; 146 tiles & Gap & $341.8(479)$ & $705.3(1071)$ & $530.8(1550)$ \\
& Outer & $297.5(417)$ & $266.1(404)$ & $281.2(821)$ \\
& Totals & $246.7(2496)$ & $368.0(4034)$ & $309.8(6530)$ \\
\hline
\end{tabular}




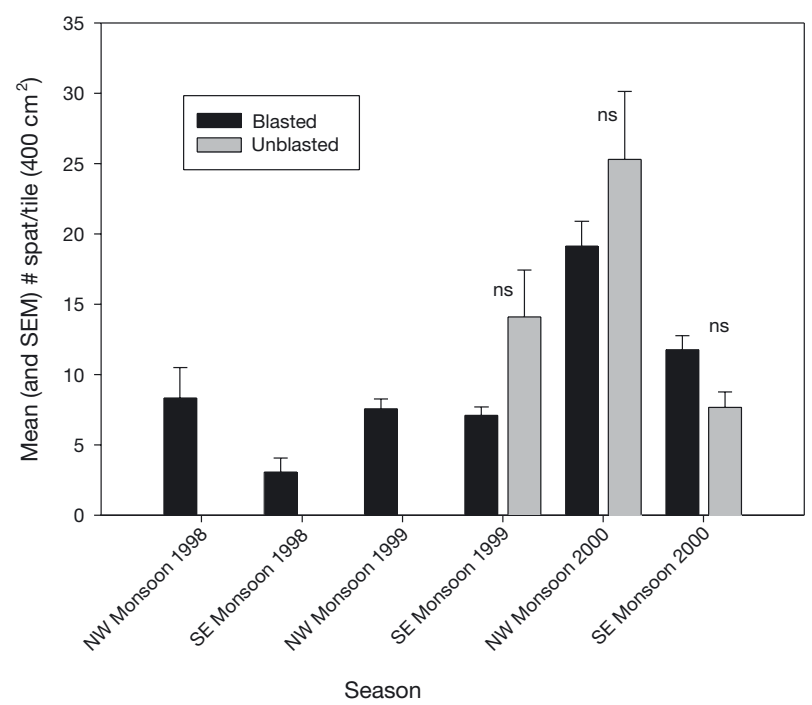

Fig. 6. Mean number of recruits per tile (and SEM) over $3 \mathrm{yr}$, pooled over blasted sites ( 3 the first yr, 9 the last 2 yr) and 6 unblasted sites. There are significant seasonal differences in recruitment, but no significant differences between blasted and unblasted sites (marked ns)

the protected and exposed surfaces (Maida et al. 1994) or the effect of current flow across the settlement plate edges (Mullineaux \& Butman 1991). Acroporids have been shown to prefer high light intensity when settling (Mundy \& Babcock 1998), consistent with the findings of increased acroporid settlement on outer tile surfaces in this study. Larval preference for different light regimes and/or habitats (crevices vs exposed) suggests the presence of strong selective pressure on early recruitment (Maida et al. 1994, Mundy \& Babcock 1998). Spat that settled inside the gap were more likely to do so on the outer border (Table 2), perhaps due to the favorable light regime at the edges or simply because the larvae reached the borders first. Maida et al. (1994) also found far higher settlement at tile edges, although they used horizontally stacked tiles rather than the vertical arrangement used here.

In Komodo, corals inside the gap environment were on average larger than those on outer surfaces, and growth rates in general also appeared to be higher than average for other regions. The growth rates of coral spat seen here (Table 3; colonies reaching sizes $>20 \mathrm{~mm}$ in $6 \mathrm{mo}$ ) are much higher than those typically reported (colonies rarely growing $\sim 10 \mathrm{~mm}$ in the first year, Harrison \& Wallace 1990).

\section{Blasted vs. unblasted sites}

Differences between mean numbers of spat in blasted and unblasted sites in Komodo National Park were not significant; there was no correlation between local coral cover and recruitment to tiles (Fig. 3). This result is in contrast to the blasted vs unblasted site comparison in Tanzania reported in Nzali et al. (1998), although in that study only 1 site of each type was examined (at the northern and southern ends of Taa reef, separated by $\sim 2 \mathrm{~km}$ ), so different current patterns may have supplied different levels of source larvae. In Komodo, settlement rates often varied considerably between sites $<2 \mathrm{~km}$ apart. The significant variation in settlement across sites could have important implications for long-term recovery from blast fishing. Gaining a better understanding of source populations and connectivity patterns among reefs in Komodo National Park would be an important next step in attempting to understand this variation.

\section{Rehabilitation potential}

The results from this study are encouraging in the context of reef rehabilitation potential for Komodo National Park. Overall, recruitment levels are high, and blasted sites show comparable levels of settlement to unblasted sites, indicating that rubble fields are unlikely to be recruitment-limited. High settlement on tiles, however, does not translate to high numbers of juveniles in the rubble fields. While the varying current patterns at the different sites in the park probably contribute to site differences in recruitment, there was no direct relationship between current strength and recruitment to tiles (Fig. 3). In contrast, it has been shown that increased current strength led to decreased survival of small corals that had recruited to rubble fields (Fox et al. 2003). Most likely, current-induced abrasion and rubble burial causes disproportionate mortality in the period between initial settlement and when the coral spat have grown large enough to be detected during field surveys on the rubble. This settlement study was conducted in the context of designing effective rehabilitation methods to reduce postsettlement mortality by creating stable structures (Fox \& Pet 2001, Fox et al. in press). With stable surfaces to settle on, coral recruitment observed in restored areas would likely be more comparable to that observed on settlement tiles.

Acknowledgements. I thank the Indonesian Institute of Sciences (LIPI), R. Dahuri, and the staff of Komodo National Park and The Nature Conservancy Komodo Field Office. The majority of this work was funded by grants from The Nature Conservancy/Mellon Foundation Ecosystem Research Program, NSF grant INT98-19837, the University of California's Pacific Rim Research Program and the International Society for Reef Studies. T. Chen, M. DeSalvo and J. Kwong assisted with settlement tile analysis; R. Caldwell, M. Gleason, M. Erdmann, J. Pet and P. Mous provided helpful advice; E. Mal- 
oney and C. Huffard provided excellent assistance in the field; R. Caldwell, F. Cox, W. Getz, M. Gleason, R. Robison, W. Sousa, and 3 anonymous reviewers provided helpful comments on the manuscript.

\section{LITERATURE CITED}

Alcala AC, Gomez ED (1987) Dynamiting coral reefs for fish: a resource-destructive fishing method. In: Salvat B (ed) Human impacts on coral reefs: facts and recommendations. Antenne Museum EPHE, French Polynesia, p 52-60

Babcock R, Mundy C (1996) Coral recruitment: consequences of settlement choice for early growth and survivorship in two scleractinians. J Exp Mar Biol Ecol 206:179-201

Babcock RC (1991) Comparative demography of three species of scleractinian corals using age-dependent and sizedependent classifications. Ecol Monogr 61:225-244

Babcock RC, Heyward AJ (1986) Larval development of certain gamete spawning scleractinian corals. Coral Reefs 5: 111-116

Baird AH, Hughes TP (1997) Spatial variation in coral recruitment around Lizard Island, Australia. Proc 8th Int Coral Reef Symp 2:1207-1210

Bak RPM, Engel MS (1979) Distribution, abundance and survival of juvenile hermatypic corals (Scleractinia) and the importance of life history strategies in the parent coral community. Mar Biol 54:341-352

Best MB, Boekschoten GJ (1988) Comparative qualitative studies on coral species composition in various reef sites in the eastern Indonesian archipelago. Proc 6th Int Coral Reef Symp 3:197-204

Best MB, Hoeksema BW, Moka W, Moll H, Suharsono, Sutarna IN (1989) Recent scleractinian coral species collected during the Snellius-II expedition in eastern Indonesia. Neth J Sea Res 23:107-115

Connell JH (1997) Disturbance and recovery of coral assemblages. Coral Reefs 16:S101-S113

Connell JH, Hughes TP, Wallace AC (1997) A 30-year study of coral abundance, recruitment, and disturbance at several scales in space and time. Ecol Monogr 67:461-488

Done T (1992) Constancy and change in some Great Barrier Reef coral communities: 1980-1990. Am Zool 32:655-662

Dunstan PK, Johnson CR (1998) Spatio-temporal variation in coral recruitment at different scales on Heron Reef, southern Great Barrier Reef. Coral Reefs 17:71-81

Edwards AJ, Clark S (1998) Coral transplantation: a useful management tool or misguided meddling? Mar Pollut Bull $37: 474-487$

Edwards AJ, Clark S, Zahir H, Rajasuriya A, Naseer A, Rubens J (2001) Coral bleaching and mortality on artificial and natural reefs in Maldives in 1998, sea surface temperature anomalies and initial recovery. Mar Pollut Bull 42: $7-15$

English SA, Baker VJ, Wilkinson CR (1997) Survey manual for tropical marine resources. Australian Institute of Marine Science, Townsville, QLD

Fisk DA, Harriott VJ (1990) Spatial and temporal variation in coral recruitment on the Great Barrier Reef (Australia): implications for dispersal hypotheses. Mar Biol 107: 485-490

Fitzhardinge RC (1988) Coral recruitment: the importance of interspecific differences in juvenile growth and mortality. Proc 6th Int Coral Reef Symp 2:673-678

Fox HE (2002) Damage from blast fishing and ecological factors influencing coral reef recovery in Indonesia. $\mathrm{PhD}$ thesis, University of California, Berkeley
Fox HE, Pet JS (2001) Pilot study suggests viable options for reef restoration in Komodo National Park. Coral Reefs 20: 219-220

Fox HE, Pet JS, Dahuri R, Caldwell RL (2003) Recovery in rubble fields: long-term impacts of blast fishing. Mar Pollut Bull 46:1024-1031

Fox HE, Dahuri R, Muljadi AH, Mous PJ, Pet JS (2001) Increased coral cover in Komodo National Park: monitoring for management relevance. Indones J Coast Mar Res (Pesisir dan Lautan) 3:26-35

Fox HE, Mous PJ, Pet JS, Muljadi AH, Caldwell RL (in press) Rehabilitating coral reefs following blast fishing: a multiscale experimental assessment. Cons Biol

Gleason MG (1996) Coral recruitment in Moorea, French Polynesia: the importance of patch type and temporal variation. J Exp Mar Biol Ecol 207:79-101

Gunkel F (1997) Effects of different substrate surface roughness on sessile invertebrate recruitment off Lee Stocking Island, Exuma Cays, Bahamas-preliminary results. Proc 8th Int Coral Reef Symp 2:1185-1190

Harii S, Kayanne H, Takigawa H, Hayashibara T, Yamamoto M (2002) Larval survivorship, competency periods and settlement of two brooding corals, Heliopora coerulea and Pocillopora damicornis. Mar Biol 141:39-46

Harriott VJ (1999) Coral recruitment at a high latitude Pacific site: a comparison with Atlantic reefs. Bull Mar Sci 65: 881-891

Harriott VJ, Banks SA (1995) Recruitment of scleractinian corals in the Solitary Islands Marine Reserve, a high latitude coral-dominated community in Eastern Australia. Mar Ecol Prog Ser 123:155-161

Harriott VJ, Fisk DA (1987) A comparison of settlement plate types for experiments on the recruitment of scleractinian corals. Mar Ecol Prog Ser 37:201-208

Harriott VJ, Fisk DA (1988) Recruitment patterns of scleractinian corals: a study of three reefs. Aust J Mar Freshw Res 39:409-416

Harriot VJ, Fisk DA (1989) The natural recruitment and recovery process of corals at Green Island. Report No. TM15. Great Barrier Reef Marine Park Authority, Townsville, QLD

Harrison PL, Wallace CC (1990) Reproduction, dispersal, and recruitment of scleractinian corals. In: Dubinsky Z (ed) Ecosystems of the world: coral reefs. Elsevier, Amsterdam, p 133-207

Harrison PL, Babcock RC, Bull GD, Oliver JK, Wallace CC, Willis BL (1984) Mass spawning in tropical reef corals. Science 223:1186-1189

Holthus P (1995) Rapid ecological assessment of Komodo National Park. The Nature Conservancy Indonesia Program, Jakarta, p 57

Hughes TP, Baird AH, Dinsdale EA, Moltschaniwskyj NA, Pratchett MS, Tanner JE, Willis BL (1999) Patterns of recruitment and abundance of corals along the Great Barrier Reef. Nature 379:59-63

Jokiel PL, Morrissey JI (1993) Water motion on coral reefs: evaluation of the clod card technique. Mar Ecol Prog Ser 93:175-181

Koehl MAR, Dobbins E, Best B, Merz R, Moore S (1998) Small-scale mixing and transport in and above coral reef during mass spawning. EOS Trans Am Geophys Union 78:OS59

Loch K, Loch W, Schuhmacher H, See WR (2002) Coral recruitment and regeneration on a Maldivian reef 21 months after the coral bleaching event of 1998. PSZN I: Mar Ecol 23:219-236

Maida M, Coll JC, Sammarco PW (1994) Shedding new light 
on scleractinian coral recruitment. J Exp Mar Biol Ecol 180:189-202

McManus JW (1997) Tropical marine fisheries and the future of coral reefs: a brief review with emphasis on southeast Asia. Coral Reefs 16:S121-S127

Mullineaux LS, Butman CA (1991) Initial contact, exploration and attachment of barnacle (Balanus amphitrite) cyrids settling in flow. Mar Biol 110:93-104

Mundy CN (2000) An appraisal of methods used in coral recruitment studies. Coral Reefs 19:124-131

Mundy CN, Babcock RC (1998) Role of light intensity and spectral quality in coral settlement: implications for depthdependent settlement? J Exp Mar Biol Ecol 223:235-255

Nacua SS, Alino PM (1994) Comparison on the colonization and recruitment of algae and sessile (sic) on three different types of recruitment plates at two sites in Bolinao, Pangasinan, Philippines. Bull Mar Sci 55:1347-1348

Nzali LM, Johnstone RW, Mgaya YD (1998) Factors affecting scleractinian coral recruitment on a nearshore reef in Tanzania. Ambio 27:717-722

Pet-Soede L, Erdmann MV (1998) Blast fishing in southwest Sulawesi, Indonesia. Naga, ICLARM Q April-June:4-9

Raymundo, L, Maypa A (1997) Interactions between corals and barnacles: the effect of barnacles on coral recruitment in Apo Island, Philippines. In: Proc 29th Ann Conf of FIMFS. Silliman University, The Philippines, p 44-56

Reyes MZ, Yap HT (2001) Effect of artificial substratum material and resident adults on coral settlement patterns at Danjugan Island, Philippines. Bull Mar Sci 69:559-566

Richmond RH (1988) Competency and dispersal potential of planula larvae of a spawning versus a brooding coral. Proc 6th Int Coral Reef Symp 2:827-831

Roberts CM (1997) Connectivity and management of Caribbean coral reefs. Science 278:1454-1457

Rogers CS, Fitz HC III, Gilnack M, Beets J, Hardin J (1984)

Editorial responsibility: Charles Birkeland (Contributing Editor), Honolulu, Hawaii, USA
Scleractinian coral recruitment patterns at Salt River submarine canyon, St Croix, Virgin Islands. Coral Reefs 3: $69-76$

Sammarco PW (1980) Diadema and its relationship to coral spat mortality: grazing competition and biological disturbance. J Exp Mar Biol Ecol 45:245-272

Smith SR (1988) Recovery of a disturbed reef in Bermuda: influence of reef structure and herbivorous grazers on algal and sessile invertebrate recruitment. Proc 6th Int Coral Reef Symp 2:267-272

Smith SR (1992) Patterns of coral recruitment and post-settlement mortality on Bermuda's reefs: comparisons to Caribbean and Pacific reefs. Am Zool 32:663-673

Smith SR (1997) Patterns of coral settlement, recruitment and juvenile mortality with depth at Conch Reef, Florida. Proc 8th Int Coral Reef Symp 2:1197-1202

Syms C, Jones GP (2000) Disturbance, habitat structure, and the dynamics of a coral-reef fish community. Ecology 81: $2714-2729$

Tomascik T, Van Woesik R, Mah AJ (1996) Rapid coral colonization of a recent lava flow following a volcanic eruption, Banda Islands, Indonesia. Coral Reefs 15:169-175

Tomascik T, Mah AJ, Nontji A, Moosa MK (1997) The ecology of the Indonesian seas. Parts $1 \& 2$. Periplus, Singapore

Wallace CC (1985) Seasonal peaks and annual fluctuations in recruitment of juvenile scleractinian corals. Mar Ecol Prog Ser 21:289-298

Wallace CC, Watt A, Bull GD (1986) Recruitment of juvenile corals onto coral tables preyed upon by Acanthaster planci. Mar Ecol Prog Ser 32:299-306

Wilson JR, Harrison PL (1998) Settlement-competency periods of larvae of three species of scleractinian corals. Mar Biol 131:339-345

Winer BJ, Brown DR, Michels KM (1991) Statistical principles in experimental design. McGraw Hill, New York

Submitted: April 2, 2003; Accepted: December 11, 2003

Proofs received from author(s): March 12, 2004 